\title{
IN VITRO PROPAGATION OF CATTLEYA LINDL. AND LAELIA LINDL. SPECIES
}

\author{
Alla M. LaVRentyeVA ${ }^{1} \&$ Roman V. IVANNIKOV ${ }^{1,2}$ \\ ${ }^{1}$ Tropical and Subtropical Plants Department, National Botanical Garden of National Academy of Sciences \\ of Ukraine, 1,Timiryazevska St., Kiev, 01014, Ukraine \\ ${ }^{2}$ Author for correspondence: ivannikov_roman@rambler.ru
}

KEY WoRDS: micropropagation, Laelia, Cattleya, protocorm, in vitro

Nowadays many wild species of South American's orchids are under threat of extinction from over-collection and habitat destruction. Many tropical native orchid species were propagated in the National Botanical Garden of National Academy of Sciences of Ukraine through a range of asymbiotic seed germination techniques and tissue culture procedures aimed to preserve a number of individuals under artificial conditions in glasshouses in the temperate zone, with the aim to protect these species from complete extinction. Our orchid collection includes plants of Cattleya and Laelia species. Some of these species are rare in the wild. To protect them from extinction the methods of propagation should be developed.

Thus the objective of this study was to elaborate a methods for mass rapid seed and clonal propagation in vitro of five Cattleya species (C. aclandiae Lindl., C. bowringiana Veitch., C. granulosa Lindl., C. intermedia Graham. ex Hooker., C. percivaliana O'Brien.), and seven Laelia species (L. anceps Lindl., L. lobata (Lindl.) Veitch., L. lundii Rchb. f. et Warm., L. mantiqueirae Pabst., L. purpurata Lind1., L. rubescens Lindl., L. sincorana Schltr.), to study the development of protocorms and seedlings in vitro ${ }^{\mathrm{a}, \mathrm{b}}$.

To obtain seeds, flowers of the studied species were self-pollinated by hand under glasshouse conditions in the National Botanical Garden. The seeds of L. rubescens were received from the Main Botanical

\footnotetext{
${ }^{\text {a }} \mathrm{NBG}$ 's collection of tropical orchids was registered in Administrative organ CITES in Ukraine (notification? 6939/19/1-10 from 23.06.2004).

${ }^{\mathrm{b}}$ The name of species are given according to $\mathrm{C}$. Withner 1990, 1991.
}

Garden (Moscow, Russia) in January 2001.Our preliminary results showed that the capsules of orchid studied usually, ripened about 9-10 months after pollination, but seeds from unripe capsules can germinate in vitro much more earlier. Therefore the seeds from immature capsules about halfway of maturation were used for sowing on Knudson medium modified by addition of $2 \mathrm{mg} / 1$ peptone, $50 \mathrm{mg} / 1$ potassium hummate, $1 \mathrm{mg} / \mathrm{l}$ activated charcoal.

Seeds from dehisced capsules were sterilized in $10 \%$ Clorox for 15 to $20 \mathrm{~min}$, in $15 \% \mathrm{H}_{2} \mathrm{O}_{2}$ for 10 min, and then rinsed two times with sterile distilled water. Undehisced immature capsules were surfacesterilized as follows: rinsed with tap water for five minutes, then flamed after spraying with $96 \%$ ethanol. Capsules were cut open and seeds were transferred to cultivation media.

The cultures were incubated in 250-ml Erlenmeyer glass flasks in the laboratory at $25-26^{0} \mathrm{C}$, photoperiod $16 \mathrm{~h}$ and relative moisture of air $70 \%$. After sowing of seeds, flasks were inspected for seed germination and pathogen infection every seven days.

Seed germination of Cattleya and Laelia species on average began after 2 or 4 weeks of culture (tab. 1). Developing embryo exceeded initial size of embryo in 2 or 4 times, forming protocorms which shape is species-specific.

The protocorms were formed by undifferentiated highly vacuolated parenchyma cells, which are surrounded by a single layer of epidermal cells. For proliferation of protocorms the MS medium supplemented by the addition of $5 \mathrm{mg} / 1 \mathrm{BAP}$ and $2 \mathrm{mg} / 1 \mathrm{NAA}$ was used. Process of protocorm formation with many meristematic apices was highly influenced by the 
TABLE 1. The terms of seeds germination and seedlings propagation of Cattleya and Laelia species.

\begin{tabular}{|c|c|c|c|c|}
\hline \multirow[t]{2}{*}{$\mathbf{N}^{0}$} & \multirow[t]{2}{*}{ Species } & \multirow[t]{2}{*}{ Start germination } & \multirow{2}{*}{$\frac{\text { Seedlings formation }}{\text { days }}$} & \multirow[t]{2}{*}{ Ex vitro transplantation } \\
\hline & & & & \\
\hline 1 & Cattleya acladiae Lindl. & 86 & 260 & 350 \\
\hline 2 & Cattleya bowringiana Veitch & 16 & 134 & 300 \\
\hline 3 & Cattleya granulosa Lindl. & 10 & 120 & 400 \\
\hline 4 & Cattleya intermedia Graham ex Hook & 97 & 323 & 871 \\
\hline 5 & Cattleya percivaliana O’Brien & 40 & 260 & 539 \\
\hline 6 & Laelia anceps Lindl. & 95 & 287 & 1458 \\
\hline 7 & Laelia lobata (Lindl.) Veitch & 11 & 240 & 1080 \\
\hline 8 & Laelia lundii Rchb.f. \& Warm. & 60 & 135 & 300 \\
\hline 9 & Laelia mantiqueirae Pabst & $5-7$ & 90 & 915 \\
\hline 10 & Laelia purpurata Lind. & 27 & 191 & 394 \\
\hline 11 & Laelia rubescens Lindl. & 17 & 270 & 930 \\
\hline 12 & Laelia sincorana Schltr. & $80-90$ & 270 & 400 \\
\hline
\end{tabular}

level and distribution of exogenic hormones in cultural media. Later, in apical zone of protocorms the formation of apex and leaf primordia of shoot was observed. This was accompanied by the differentiation of procambial and conducting bundles.

Seedling formation, in average, took about 700 days (tab. 1). By the time seedling were transferred to glasshouse culture conditions. More over, seedling (and plantlets) also may be use as a secondary explants to enlarge the coefficient of propagation.

It should be noted that the process of ontogenesis of Laelia and Cattleya seedlings are quite similar. The differences are only in terms and details of development. The development of individuals in juvenile population of seedlings is not similar in vitro. The investigation has shown, that the seedlings have some pathways of ontogenesis in vitro. It was established, that at the initial stages of seedlings ontogenesis in vitro go through two basic patterns of development. For majority of species studied formation of secondary protocorms on primary protocorms are typical. The number of the seedlings, which have been developing through each of patterns, depends not only on abiotic factors complex. It is defined by interaction: a genotype $\leftrightarrow$ a nutrient medium composition.

Different methods of clonal plant micropropagation of Cattleya and Laelia cultivars genotypes were developed in vitro culture. For propagation young growing shoots of $10-15 \mathrm{~cm}$ in height were selected. Apical and lateral shoots were used as initial explants. The buds of basal part of shoot had the highest morphogenetic potencies. Buds of some species after 6 months of cultivation on nutrient medium formed about 70 protocorms, while the middle part of shoot formed not more than 10-15 protocorms. So, we determined that apical meristems of young shoots of all genotypes studied are inert under cultivation in vitro. It doesn't develop later. Explants ability to regenerate depends on phase of plant-donor development. Buds found in May-June form protocorms more intensively and quickly, that is provoked by increasing of phytohormonal complex activity of plants in this period. We used different modifications of nutrient media for cultivation of Cattleya's and Laelia's explants. Optimal medium for protocorm proliferation was MS with $5 \mathrm{mg} / 1 \mathrm{BAP}, 2 \mathrm{mg} / 1$ NAA, $100 \mathrm{mg} / 1$ peptone, $15 \%$ coconut milk, $1.5 \mathrm{~g} / 1$ activated charcoal. More intensively protocorms were formed in darkness. The most active zones of protocorm formation are bases of leaf primordiums and bud squamules. As a rule 4-5 meristematic centers with lots of protocorms form simultaneously, they can be divided and cultivated.

Our research was carried out to examine the suitability of the basal and lateral buds of young shoots as explants for mass rapid clonal propagation of 
species studied. The size of these explants did not exceed $0,5-1,0 \mathrm{~cm}$. It was established that basal buds of shoot have the highest morphogenetic potencies.

Thus, combining some methods of seed and micropropagation in vitro we can get planting material of these beautiful ornamental plants. Effective method of Cattleya and Laelia plants micropropagation is induction of protocorm formations on leaves of plantlets and seedlings. Leaves were carefully separated from stem and cultivated on MS with $2 \mathrm{mg} / 1$ BAP, $0.3 \mathrm{mg} / 1 \mathrm{NAA}, 15 \%$ coconut milk. After one month at the base of leaves, at first from epidermal tissues form numerous of protocorms, followed by shoots formation.

Alla Lavrentyeva was educated at the National Agrarian University in Kiev, Ukraine. Since 1975 she works in M.M. Grishko National Botanical Garden of NASU as a senior researcher at the seed and micropropagation lab, where she received her $\mathrm{PhD}$ degree in biology on Optimization of microclonal propagation of Cymbidium hybr. in vitro. She published more than 100 articles and some books on this topics.

Roman Ivannikov was born in 1974 in Romni, Ukraine. Then he was educated at the Tarasa Shewscenka National University of Kiev, Ukraine. Now he works at M.M. Grishko National Botanical Garden of NASU as a senior researcher at the seed and micropropagation lab, where he received his $\mathrm{PhD}$ degree in biology on Biology of development of the species of genus Laelia Lindl. (Orchidaceae Juss.) under the conditions of greenhouse and in vitro. He interesting in Reproductive Biology and Conservation of some tropical genus of Orchidaceae in vitro. He published more than 30 articles on these topics. 